\title{
PERCEPTUAL MOTOR PROGRAM PADA AUTISTIC DISORDER
}

\author{
Danisa Nurul Fatimah' ${ }^{1)}$ Nesi $^{2)^{*}}$ \\ 1)danisanurul99@gmail.com, Politeknik Kesehatan Hermina \\ 2) nesiaureole@gmail.com, Politeknik Kesehatan Hermina \\ *penulis korespondensi
}

\begin{abstract}
Autistic disorder is a complex developmental disorder that includes communication, social interaction, and imaginative activity. Autistic disorder is a condition characterized by impaired speech and reciprocal social skills, as well as repetitive and abnormal behavior. Autistic disorder has a different mindset and sensory dysregulation. This disorder can affect their ability to live independently. This journal aims to explain the perceptual motor program in autistic disorder. The research method used is descriptive qualitative with retrieval of material based on literature review. The results showed that giving a perceptual motor program could increase concentration, improve balance (vestibular) sensory abilities, improve visual (visual) sensory abilities, and increase proprioceptive sensory abilities in autistic disorder.
\end{abstract}

Keywords : autistic disorder; sensory; perceptual motor program

\begin{abstract}
Abstrak
Autistic disorder adalah suatu gangguan perkembangan kompleks meliputi komunikasi, interaksi sosial, dan aktivitas imajinasi. Autistic disorder memiliki pola pikir dan disregulasi sensorik yang berbeda. Gangguan ini dapat mempengaruhi kemampuannya untuk hidup mandiri. Jurnal ini bertujuan untuk menjelaskan tentang perceptual motor program pada autistic disorder. Metode penelitian yang digunakan deskriptif kualitatif dengan pengambilan materi berbasis literatur rivew. Hasil penelitian menunjukan bahwa pemberian perceptual motor program dapat meningkatkan konsentrasi, meningkatkan kemampuan sensorik keseimbangan (vestibular), meningkatkan kemampuan sensorik penglihatan (visual), dan meningkatkan kemampuan sensorik proprioceptive pada autistic disorder.
\end{abstract}

Kata kunci : autistic disorder; sensorik; perceptual motor program

\section{PENDAHULUAN}

Tumbuh kembang adalah gabungan dari dua kata yang mencakup peristiwa dengan sifat yang berbeda namun saling berkaitan dan sulit untuk dipisahkan yaitu pertumbuhan dan perkembangan (Shodiq, 2015). Pertumbuhan adalah perubahan kuantitatif, artinya adanya peningkatan jumlah, ukuran, dan dimensi pada tingkat sel, organ, dan individu (Soetjiningsih dan Ranuh, 2015). Sedangkan, perkembangan yaitu peningkatan kemampuan dan keterampilan dalam struktur fungsi fisik yang menjadi lebih kompleks dalam pola yang teratur sebagai hasil dari proses pematangan (Moonik dkk, 2015). Proses tumbuh kembang dimulai dan berlangsung seumur hidup sejak bayi masih dalam kandungan. Selama proses pertumbuhan dan perkembangan awal, dapat terjadi berbagai hal yang menyebabkan anak mengalami gangguan tumbuh kembang. Anak yang mengalami gangguan ini disebut anak penyandang disabilitas. Menurut data Sistem Informasi Manajemen Penyandang Disabilitas (SIMPD) dari Kementerian Sosial, diantara penyandang disabilitas di Indonesia, sebanyak 1,70\% merupakan penyandang disabilitas autistic disorder (Infodatin, 2019).

Salah satu kasus contoh anak penyandang disabilitas yaitu Autistic disorder. Autistic disorder adalah suatu gangguan perkembangan kompleks meliputi komunikasi, interaksi sosial, dan aktivitas imajinasi. Autistic disorder adalah anak yang mempunyai gangguan dalam bidang komunikasi, interaksi sosial, gangguan sensorik, pola bermain, dan emosi (Matson, 2006). Menurut Dominica (2012), autistic disorder adalah suatu kondisi yang ditandai dengan gangguan bicara dan keterampilan sosial timbal balik, serta perilaku berulang dan abnormal. Autistic disorder memiliki pola pikir dan disregulasi sensorik yang berbeda (Dominica, 2012). Gangguan ini dapat mempengaruhi kemampuan anak autistic disorder untuk hidup mandiri (Dominica, 2012). Menurut Rudy (2018) dan Kementerian Pemberdayaan Perempuan dan 
Perlindungan Anak (PPPA) mengatakan bahwa penderita autistic disorder dapat terjadi pada siapa saja, tidak memandang keadaan tingkat sosial, suku, ras, budaya, dan etnis. Tujuan dilakukannya penelitian perceptual motor program pada autistic disorder ini adalah untuk membantu anak dengan autistic disorder untuk meningkatkan kemampuan sensory nya.

\section{METODE}

Metode penelitian ini menggunakan deskriptif kualiatif dengan pengambilan materi berbasis literatur rivew. Artikel yang digunakan pada penelitian ini diperoleh dari google scholar.

\section{HASIL DAN PEMBAHASAN Etiologi}

Menurut Sari (2009) autistic disorder merupakan penyakit multifaktor. Penyebab terjadinya autistic disorder belum diketahui secara pasti. Menurut beberapa penelitian, penyebab autistic disorder adalah kerusakan jaringan otak yang terjadi 20 hari sebelum terjadi pembentukan janin (Rodier dkk, 1996 ; Rodier, 2002), infeksi yang disebabkan oleh toksoplasmosis, rubella, candida, keracunan logam berat, zat aditif (MSG, pengawet, pewarna) dan obat-obatan lain (Handjono, 2004), serta adanya kelainan pada sistem saraf (neurologi) (Faisal Yatim, 2007).

\section{Insiden dan Prevalensi}

Kementerian PPA (2018) I Gusti Ayu Bintang Darmawati menyatakan bahwa penyandang autistic disorder laki-laki lebih banyak dibanding perempuan (5:1). Jumlah kasus autistic disorder di dunia semakin hari semakin meningkat. UNESCO menetapkan pada tahun 2011 penyandang autistic disorder di dunia ada sekitar 35 juta orang, yang artinya rata-rata 6 dari 1000 orang di dunia mengidap autistic disorder. Penelitian yang dilakukan Center for Disease Control (CDC) Amerika Serikat tahun 2008 menyatakan bahwa, rasio anak usia 8 tahun yang terdiagnosa autistic disorder dengan anak normal adalah 1:80. Penelitian Hongkong (2008) melaporkan tingkat kasus autistic disorder dengan jumlah kasus 1,68 per 1000 untuk anak dibawah 15 tahun. Saat ini belum ada penelitian khusus yang dapat memberikan data autistic disorder pada anak di Indonesia. Dengan prevalensi autistic disorder yang terjadi pada anak di Hongkong, dimana jumlah anak usia 5-19 tahun di Indonesia mencapai 66.000.805 jiwa (BPS, 2010), maka dapat diperkirakan anak penyandang autistic disorder di Indonesia pada rentang usia 5-19 tahun terdapat lebih dari 112 ribu.

\section{Manisfestasi Klinis}

Permasalahan yang biasanya ditemui pada kondisi autistic disorder adalah adanya gangguan atensi pada visual dalam bidang interaksi sosial, komunikasi sosial dan imaginasi berfikir fleksibel dan bermain imaginative, gangguan sensoris, gangguan reflek, gangguan penurunan kekuatan otot, dan gangguan aktivitas fungsional berdiri dan berjalan (Matson, 2006). Berbagai gangguan ini dapat diperbaiki dengan pemberian terapi sejak dini.

\section{Intervensi Fisioterapi}

Gejala autistic disorder biasanya muncul pada anak di bawah usia 3 tahun (Yuwono, 2009:26). Autistic disorder adalah salah satu gangguan pertumbuhan dan perkembangan yang paling umum, dan semua anak memiliki gejala atau kondisi yang berbeda. Autistic disorder tidak bisa disembuhkan dengan obat, tetapi dengan diagnosis dan intervensi yang lebih awal, sebagian anak autistic disorder dapat membaca, berbicara, mendengar dan menulis.

Fisioterapi adalah pelayanan kesehatan yang diberikan oleh fisioterapis untuk mengoptimalkan kualitas hidup dengan cara mengembangkan, memelihara, dan memulihkan gerak dan fungsi yang berpotensi terganggu oleh faktor penuaan, cedera, penyakit, gangguan fisik dan faktor lingkungan sepanjang siklus hidup, melalui metode manual, peningkatan 
kemampuan gerak, penggunaan peralatan, pelatihan fungsi dan komunikasi (Standar kompetensi fisioterapi Indonesia, 2020). Sesuai dengan definisinya, fisioterapi membantu anak dengan autistic disorder untuk meningkatkan kemampuan sensory nya. Modalitas fisioterapi yang digunakan pada kasus autistic disorder antara lain play exercise, hidroterapi, terapi menari, terapi rekreasi dan hippotherapy (terapi menunggang kuda) (Arifadhi dkk,2019).

Play therapy adalah penggunaan pola bermain sebagai media yang efektif untuk kebebasan bereksplorasi dan berekspresi (Arifadhi, T., \& Susanti, N. 2019). Bermain adalah bagian dari masa kanak-kanak dan merupakan media untuk mempromosikan ekspresi verbal, keterampilan komunikasi, perkembangan emosional, keterampilan sosial, pengambilan keputusan, dan perkembangan kognitif anak (Puspaningrum, 2010). Salah satu contoh metode play therapy yaitu perceptual motor program.

Metode perceptual motor program bertujuan untuk memperoleh kemampuan dan keterampilan fungsional melalui input sensorik, integrasi sensorik, interpretasi motorik, aktivitas motorik, dan umpan balik (Gallahue 2002 dalam Maryatun, 2012). Menurut (Kepart, 1967) metode perceptual motor program dapat mengembangkan persepsi anak. Perkembangan persepsi mengarah pada proses motorik yang menghasilkan peningkatan sensorik. Sensoris tersebut terdiri dari Visual atau penglihatan, Auditori atau pendengaran, Taste atau kesadaran, Touch atau sentuhan, Taktile atau respon tekanan, Smell atau kemampuan mencium, Proprioceptive atau pengenalan sendi, serta Vestibular atau keseimbangan mempengaruhi proses kognitif anak (Pigaet dalam Tiara, 2018). Sesuai dengan tujuan modalitas Perceptual Motor Program yang mampu meningkatkan keterampilan motorik anak dimulai dengan proses persepsi yang tersimpan dalam memori. Kemudian persepsi tersebut akan mengakomodasi pada indra. Melalui panca indra yang menerima stimulus atau rangsangan dari luar, atau dari proses atensi yang akhirnya membuat adanya peningkatan sensoris dengan menggunakan modalitas Perceptual Motor Program (Nugroho, 2019).

Dalam pelaksanaan Perceptual Motor Program fisioterapi dituntut untuk kreatif dalam memberikan stimulasi yang sesuai untuk menstimulasi anak. Misalnya fisioterapi dapat melatih anak berjalan diatas balok panjang yang tujuannya untuk meningkatkan konsentrasi dan keseimbangan. Hal ini akan merangsang sistem vestibular memproses informasi mengenai keseimbangan dan gerakan oleh reseptor sensorik di telinga bagian dalam, mata, leher bagian atas, dan tubuh. Sistem vestibular merupakan sistem sensorik yang berperan penting dalam keseimbangan, kontrol kepala, dan gerakan pada bola mata. Reseptor vestibular terdapat pada telinga bagian dalam. Dengan adanya aktivitas dari play therapy maka impuls gerakan akan diubah menjadi impuls saraf oleh reseptor vestibular, reseptor visual dan reseptor propioseptik. Impuls tersebut akan dihantarkan oleh saraf afferen vestibularis ke otak. Setelah sampai di otak, otak akan memproses informasi yang masuk dan akan memberi respon yang sesuai. Dengan latihan ini diharapkan dapat meningkatkan anak lebih berkonsentrasi terhadap tantangan dan kemampuan menjaga keseimbangannya dapat meningkat (Rahmayani, 2018).

Penatalaksanaan fisioterapi pada kasus autistic disorder dengan metode Perceptual Motor Program terbukti efektif dapat meningkatkan konsentrasi, meningkatkan kemampuan sensorik keseimbangan (vestibular), meningkatkan kemampuan sensorik penglihatan (visual), dan meningkatkan kemampuan sensorik proprioceptive pada autistic disorder (Rahmayani, 2018). Hal ini didukung oleh penelitian dari (Widiantara dkk, 2020) menyatakan Perceptual Motor Program dapat menstimulasi banyak komponen yang mempengaruhi keseimbangan seperti mekanisme adaptasi, strategi sensori, internal representasi, kekuatan otot, postural kontrol, visual, dan vestibular. Penelitian dari (Nugroho, 2019) menyatakan Perceptual Motor Program membantu peningkatan sensoris pada anak autistic disorder. 


\section{PENUTUP}

Berdasarkan uraian diatas dapat disimpulkan bahwa autistic disorder adalah suatu kondisi yang ditandai dengan gangguan bicara dan keterampilan sosial timbal balik, serta perilaku berulang dan abnormal. Anak autistic disorder juga memiliki pola pikir dan disregulasi sensorik yang berbeda. Permasalahan yang biasanya ditemui pada kondisi autistic disorder adalah adanya gangguan atensi dalam bidang interaksi sosial, komunikasi sosial dan imaginasi berfikir fleksibel dan bermain imaginative, gangguan sensoris, gangguan reflek. Penanganan Fisioterapi yang akan diberikan adalah pemberian metode Perceptual Motor Program. Pemberian modalitas ini diharapkan dapat meningkatkan konsentrasi, meningkatkan kemampuan sensorik keseimbangan (vestibular), meningkatkan kemampuan sensorik penglihatan (visual), dan meningkatkan kemampuan sensorik proprioceptive pada autistic disorder.

\section{DAFTAR PUSTAKA}

Arifadhi, T., \& Susanti, N. (2019). Pengaruh Penatalaksanaan Fisioterapi Pada Anak Kondisi Autisme Dengan Modalitas Play Exercise (Perceptual Motor Program) Dan Hidroterapi (Balance and Coordination) Di YPAC Surakarta. Pena Jurnal Ilmu Pengetahuan dan Teknologi, 33(2), 53-62.

Moonik, P., Lestari, H., \& Wilar, R. (2015). Faktor-faktor yang mempengaruhi keterlambatan perkembangan anak taman kanak-kanak. e-CliniC, 3(1).

Nugroho, K. A., Widodo, A., \& Fis, S. (2019). Penatalaksanaan Fisioterapi Pada Kasus Autis Di Pusat Layanan Autis Kab. Sragen (Doctoral dissertation, Universitas Muhammadiyah Surakarta).

Prevalensi Autisme. (2018). (https://kemenpppa.go.id/index.php/page/read/31/1682/hari$\begin{array}{lll}\text { peduli-autisme-sedunia-kenali-gejalanya-pahami-keadaannya) } & \text { Mengunjungi } 7\end{array}$ Desember 2021

Rahmayani, N., Wijianto, S. S., \& Or, M. (2018). Penatalaksanaan Fisioterapi pada Kasus Autism Spectrum Disorder (ASD) dengan Modalitas Massage Therapy dan Play Therapy di Pusat Layanan Autism Sragen (Doctoral dissertation, Universitas Muhammadiyah Surakarta).

Standar Kompetensi Fisioterapi Indonesia. (2020).

Widiantara, I. M. A., Purnawati, S., Irfan, M., Lesmana, C. B. J., Wihandani, D. M., \& Tirtayasa, K. (2020). Perceptual Motor Approach lebih baik daripada Specific Balance Training dalam meningkatkan keseimbangan dinamis pada anak dengan Autism Spectrum Disorder (ASD) derajat 1 di Pusat layanan autis kota Denpasar.

Yatim, F. L. (2002). Autisme: suatu gangguan jiwa pada anak-anak. Yayasan Obor Indonesia. 